\title{
HOW DO INFORMATION SYSTEMS (IS) PROGRAMS PREPARE STUDENTS FOR ENTRY-LEVEL OCCUPATIONS IN THE COMPUTER AND IT INDUSTRY?
}

\author{
Lisa Z. Bain, Rhode Island College, Ibain@ric.edu \\ Neelima Bhatnagar, University of Pittsburgh Johnstown,Bhatnagar@pitt.edu \\ Thomas A. Chapman, University of Mississippi, tchapman@bus.olemiss.edu
}

\begin{abstract}
Information Systems (IS) programs strive to prepare students for jobs in the Computer and IT industry. These programs use various names, which causes confusion for students in choosing a program and understanding occupations available for IS-related majors. This research study examined the differing names of IS programs in three states, identified the main types of occupations, and evaluated three different IS programs and the IS 2010 model curriculum on how well the courses prepared students for these jobs, focusing on entry-level. The results showed that there are 20 different names for IS-related programs and two main tracks for entry-level occupations. Of the IS programs evaluated, each prepared students for one of the main tracks but not the other (with a few minor exceptions). These results could be used by faculty to evaluate the type of IS program at their institution and make adjustments to best suit the local job market.
\end{abstract}

Keywords: IT Careers, IT Occupations, Entry-Level Positions, Job Titles, Student Engagement, IS Program Names

\section{INTRODUCTION}

The art of teaching college students is constantly evolving and improving to meet the demands of students. Students have changed and will continue to change for the foreseeable future. Therefore, engaging these students in complex topics and theories is more challenging than it was even five or 10 years ago. Computer technology also continues to change. The invention of devices like the iPhone and iPad have allowed consumers with little to no computer skills to use and benefit from the technology. This continues to spread into other areas of our daily lives and is more prevalent. Organizations creating these products need employees with computer skills. A much higher level skill set is needed to develop and support this environment. Our job in preparing students to fill these roles can be extremely rewarding but also very challenging. Many advanced computer and technology concepts are difficult to learn. How do we as Information System educators incentivize students to focus on their courses and fully engage in the materials? How do we recruit students to take on these difficult majors? One approach would be to use a carrot on a stick. In other words, enticing students with a prize (job) in order to increase their interest level and work ethic. Making them aware of the job market and the needs for technical skills could play a significant role in improving IS student engagement.

\section{Student Awareness of Computer and IT Occupations}

The first step in approaching student engagement would be to understand IS student awareness and understanding of computer and IT occupations. A previous study by one of the authors showed that $89 \%$ of the CIS students surveyed in 2016 were not familiar with the types of jobs/careers available for CIS majors (Bain, Choi \& Hayden, 2016). This resulted in the need to educate students in this area. The thinking here was that if students understand the job market better than they would therefore recognize the direct link between the course materials to their future career. At least that is the hope. However, this also resulted in the need to identify the types of jobs/careers in the IT industry as well as which courses prepare students for each job. 


\section{Types of Computer and IT Occupations}

A standardized list of computer and IT occupations does not exist. There are many lists available from a variety of sources like the U. S. Department of Labor Statistics Occupation Outlook Handbook and Robert Half Technology but these and others use different job titles for similar occupations. The IS 2010 Curriculum Guidelines for Undergraduate Degree Programs in Information Systems also has a list of IT occupations called career tracks. These lists can be confusing and overwhelming for students to read and understand. To further complicate the situation, businesses and organizations may use varying job titles for similar positions as well as job sites like Dice (www.dice.com) and glassdoor (www.glassdoor.com). It quickly became apparent that it would be essential to identify the major career tracks, the main job titles and the level of the position. Simply creating a list of computer and IT occupations would not provide the type of information to help students truly understand the industry. This research study would need to research, compile, consolidate, and possibly expand upon information available from existing sources.

\section{Relating IS Courses to Computer and IT Occupations}

The next vital piece of information that would be needed was to understand how individual courses in IS programs relate to the job information from the previous step. Students would need to understand which courses would prepare them for the job or jobs that interest them the most. Like the previous step, some basic information was already available, mostly coming from the IS 2010 Curriculum Guidelines for Undergraduate Degree Programs in Information Systems. This document provided a basic framework from which to start. Most importantly, the IS 2010 document includes a method for associating a course to a job title using one of two codes. The first being for "Significant Coverage" and the second one for "Some Coverage". However, IS programs vary from institution to institution and do not always include all the recommended courses by IS 2010. A customized table or chart would be needed for each program. This chart would provide a direct connection between IS courses and how each would, or would not, prepare a student for a specific job title.

\section{IS Program Names}

Recruitment, retention, and engagement of students in IS related disciplines continues to be a challenge. There are several reasons for this. First, despite the fact that the IS discipline has been around for a long time, a clear understanding of what the IS discipline is all about, what is offers, what it entails, and the types of jobs one can seek upon obtaining an undergraduate degree is still not well understood by today's generation of students (Bain, Choi, \& Hayden, 2016). One dimension that adds to the confusion is that there is no consensus among colleges and universities as to what an IS program should be named (Lenox, Jesse \& Woratschek, 2010). This disparity may result from accreditation requirements (e.g. AACSB, ABET) or it may be a result of how to best "market" the program to prospective students.

A comprehensive list of colleges and universities for the states of Mississippi (MS), Pennsylvania (PA), and Rhode Island (RI) was obtained from various sources including The National Center for Education Statistics, www.naviance.com, and the College Board. The types of institutions not included in this study were Art schools, Seminary and Bible schools, Colleges of Health Sciences, and Online schools. Only four-year public schools granting baccalaureate degrees were considered. This resulted in a total of 115 institutions in Pennsylvania, six in Rhode Island, and eight in Mississippi being included in this study. Results show that of the 129 schools, $78(60 \%)$ have an IS-related program and $52(40 \%)$ do not. However, 75 schools (about 58\%) do offer a degree in Computer Science while $50(39 \%)$ do not. Four out of the six institutions (67\%) in Rhode Island do not have an IS-related program but half of the schools (50\%) do offer a degree in Computer Science. In the state of Mississippi, four out of the eight schools $(50 \%)$ offered a program of study in either Computer or Management Information Systems. Five of the schools (63\%) offer degrees of study in Computer Science, albeit the subset of schools who offer degrees in Information Systems and Computer Science do not necessarily align. In Pennsylvania, 71 of the schools (62\%) offer an IS-related degree and $44(58 \%)$ offer a degree in Computer Science. 
Table 1. Count of IS-Related Program Names

\begin{tabular}{|l|r|r|r|r|r|}
\hline & \# of Schools & \multicolumn{2}{|c|}{ IS Program* } & \multicolumn{2}{c|}{ CS Program } \\
\hline & & \multicolumn{1}{|c|}{ Y } & N & Y & N \\
\hline MS & 8 & 5 & 3 & 5 & 3 \\
\hline PA & 115 & 71 & 44 & 67 & 44 \\
\hline RI & 6 & 2 & 4 & 3 & 3 \\
\hline Total & 129 & 78 & 51 & 75 & 50 \\
\hline
\end{tabular}

Further analysis of the data revealed that the 129 schools use 20 different IS-related program names. Table 2 shows the most common names are Computer Information Systems, Information Sciences and Technology, Information Technology, Management Information Systems and Information Systems, respectively. Below is a breakdown of the number of schools offering each of these degree programs:

Table 2. Common IS-Related Program Names

\begin{tabular}{|l|r|r|}
\hline \multicolumn{1}{|c|}{ Program Name } & \# of Schools & \% \\
\hline Computer Information Systems & 13 & $10 \%$ \\
\hline Information Sciences and Technology & 13 & $10 \%$ \\
\hline Information Technology & 13 & $10 \%$ \\
\hline Management Information Systems & 12 & $9 \%$ \\
\hline Information Systems & 9 & $7 \%$ \\
\hline
\end{tabular}

The complete list of the 20 IS-related program names and the count in parenthesis are Computer and Information Science (2), Computer and Information Studies (1), Computer and Information Technology (1), Computer Information Science (2), Computer Information Systems (13), Computer Information Systems and Technology (1), Computer Systems Technology (1), Computer and Information Systems (1), Computing and Information Studies (1), Computing Technology (1), Information and Technology Management (1), Information Management (1), Information Science (2), Information Sciences and Technology (13), Information Systems (9), Information Technology (13), Information Technology Management (1), Management Information Science (1), Management Information Systems (12), and Management of Information Technology (1).

But ultimately what matters is not what a program may be named, but the courses offered within a program and how these courses map to entry-level occupations. The purpose of this research study is to improve student engagement and recruitment by educating students about computer and IT occupations. This research paper provides the results of developing both a list of Computer and IT Occupations as well as a chart/figure relating to these courses in IS programs.

\section{LITERATURE REVIEW}

\section{IS as a Major}

IS faculty have to work off the basic assumption that IS majors want to be IS majors and chose to be an IS major on sound reasoning. Students major in IS or don't major in IS for a variety of reasons. A fascination of technology draws many to IS for a major and a career (Brooks, 2014). While others find the computer field as boring or just not as interesting as other business majors (Burns, 2014). However, students do tend to see computers skills as providing them a competitive advantage during their job search after college (Chipidza, 2016). Students majoring in IS-related programs does vary among institutions and there are ups and down in enrollments. Many institutions have implemented programs to help promote the major (Li, 2014). State and federal governments are also promoting the STEM and technical fields as a way to attract businesses and improve the overall economy (CS4RI, 2016). It is important to note that many Computer Science programs are seeing an increase in enrollments (Lytle, 2012). Enrollments in Information Systems seem to be increasing as well (Thatcher, 2017). Regardless of why students choose an IS major or the ups and downs of enrollments, it is essential that students understand the career opportunities 


\section{Issues in Information Systems \\ Volume 18, Issue 3, pp. 78-88, 2017}

for any chosen major/career. Some majors are easier to understand than others (e.g. nursing, education). The computer and IT industry continues to change dramatically, which is a blessing (many job opportunities) and a curse (complexities). IS programs must adapt.

\section{IS Curriculum}

As the IT field continues to change to meet the needs of businesses, so must IS curricula adapt to meet the needs of students trying to obtain entry-level jobs. Model curriculums, like IS 2010, attempt to do just that by recommending a set of courses that should guide changes in IS programs. These models are developed using IS professional organizations and IS faculty. Another approach is developing curriculum models by evaluating emerging trends in the literature (Hayen, 2012). This can identify a variety of key areas and resulting skills sets like cloud computing and virtualizations. Researchers have also used employer surveys to identify specific skills and new occupational areas. One such study identified an increase in demand for project management and big data skills (Janicki, 2014). The good news is that multiple approaches help to identify more information that can be used by faculty who are responsible for the IS curriculum at their respective institutions. On the flip side, even the most recent model curriculum (IS 2010) is not uniformly followed. A study of 394 programs showed that of the seven core courses recommended by IS 2010, the percentages of program offering these ranged from as low as $13.5 \%$ to a high of $87.3 \%$ (Hwang, 2014). (Vetri, 2011) attempted to address this issue by developing a mapping framework that could be used to assess curriculum. All of this results in a situation where IS programs vary from institution to institution with little or no consistent industry guidelines.

\section{Computer and IT Occupations}

Another important aspect to IS programs is the link between the courses and finding an occupation upon graduation. Students cannot begin this process until they know what type of occupations are available. There are general perceptions about the IT workforce as well as confusion about IT occupations (Munroe, 2012). Many different types of occupations exist as well as a variety of job titles. To add to the confusion, the same type of occupation may have multiple names for the job titles. Computer programmer versus software developer versus application developer is just one example. Job descriptions for computer programmers tend to focus on writing and testing code while descriptions for software/application developer tend to include a broader role in creating an information system to address users' need. The U.S. Department of Labor does have slightly different job descriptions for each one and organizations may use whatever job title they choose in the job postings. Introductory computer courses can help students understand the IS field (Akbulut, 2015). However, not all institutions have or require these courses. One study of IS graduates showed that the students felt they were "prepared/somewhat prepared" for their jobs (Legier, Woodward \& Martin, 2013). Ideally, faculty would want this to be "prepared". Another study showed that students were not sure of their plans after college (Lenox, Jesse, \& Woratschek, 2012). This could be attributed to a variety of factors, including confusion about IT occupations. A survey of 200 freshman showed business students are not informed about careers in other majors as well but listed Computer Information Systems lowest (Snyder \& Slauson, 2014). The Computer and IT industry provides many opportunities to students but may be a challenging web of occupations and job titles that are confusing to students.

\section{Entry-Level Occupations}

Model curriculum are useful to guide IS program development but are they focused on the IT industry as a whole or entry-level occupations. As previously mentioned, many studies document the type of skills needed for IS occupations. Other studies show a gap between the IT skills and IS curricula (Aasheim, Shropshire \& Kadlec, 2012). In fact, one study specifically looked at both IS 2010 and ABET CAC specifications and showed a "disconnect" between IS 2010 and industry specifications (Feinstein, 2014). While another study found IS 2010 to be flexible and allowing IS programs to adjust their curriculum as needed (Surendran, Amer \& Schwieger, 2012). Hwang found that creating tracks within IS programs do address skills required for entry-level positions (Hwang \& Curl, 2014). Unfortunately, they also found that tracks are not widely implemented across institutions. Interviews with IT professionals can help to understand desired skill sets as well, as long as they are focused on entry-level occupations. Lang, Jones \& Leonard (2015) did just that and found both soft and hard skills for specific occupations. With a lack of consistency across IS programs, at a minimal there should be a consistent definition of IS as a field. Westfall (2012) 


\section{Issues in Information Systems \\ Volume 18, Issue 3, pp. 78-88, 2017}

simply suggests that the purpose of education should be preparing students for employment in the field. Therefore, IS programs should be preparing IS majors for entry-level occupations.

\section{RESEARCH METHODOLOGY}

Ultimately, the purpose of this research project is to improve student engagement by educating IS students about career opportunities that directly relate to their IS courses. In order to do this, it was essential to do some background work before this could be done. This resulted in two essential steps. Step One was to identify the main types of occupations for IS majors. Step Two was to relate or link each course in an IS program in some way to each of these occupations that would allow for the creation of an IT Career Index. This index would provide some relative measure that could be used to evaluate and compare the programs. These steps would then help answer the following research questions.

Research Question 1 (RQ1): What are the main types of IS occupations for IS majors?

Hypothesis: The IS industry provides a significant number (seven or higher) of IS occupations for IS majors.

Research Question 2 (RQ2): How do IS programs prepare students for IS Occupations?

Hypothesis: IS programs provides a majority (IT Career Index 14 or higher) of the skillsets needed for entry-level IT positions.

The reasoning here is that faculty could use this information to understand how their IS programs prepare students for IT careers. It could also highlight areas for new courses, adjustments to curriculum or other opportunities for changes. Although undergraduate education should not solely focus on the job market, it should play a significant role on IS programs particularly. It is assumed that most IS programs also include general education courses, cognates, and business courses as well. These other courses provide the liberal arts and well-rounded students that most employers desire. Therefore, the core of the IS program would have the luxury of developing the IT and technical skillsets for specific occupations. Three different IS programs (one CIS, one IS and one MIS) were used for this project in order to test the occupations and index. In addition, the researchers wanted to evaluate the IS 2010 Model Curriculum since it is the standard for IS programs. The following section provide detailed information on the results.

\section{RESULTS}

Once the required steps were established for identifying the critical information on IS occupations, the work could be done to document each item. This resulted in the need to create visuals that would help students and faculty better understand the information. The IS Occupations were organized into a chart similar to an organization chart used by businesses and included IT Career Levels and Tracks. The chart was too large for this research paper and was reformatted for brevity in Table 3. Microsoft Excel was used to create the IT Career Index for each program, which are summarized in Table 4.

\section{Results for Step One (RQ1) - Main Types of IS Occupations}

There are no industry standards for the main types of IT occupations. Organizations are free to use whatever job titles they need to meet their business objectives. While some industries, like nursing or accounting, seem to have consistent job titles and roles, this is not the case in the IT industry. Therefore, this research project needed to identify the closest possible thing to a standard and that is the Occupation Outlook Handbook $(\mathrm{OOH})$ developed by the U.S. Department of Labor, Bureau of Labor Statistics (www.bls.org/ooh). This resource provides information about hundreds of occupations, which are organized into Occupational Groups. It also provides detailed information about each type of job. This includes items like What They Do, Work Environment, How to Become One, Advancement, and Pay. OOH lists all IT jobs under the group called Computer and IT Occupations. These ten occupations are listed in alphabetical order and are Computer and Information Research Scientists, Computer Network Architects, Computer Programmers, Computer Support Specialists, Computer Systems Analysts, Database Administrators, Information Security Analysts, Network and Computer Systems Administrators, Software Developers, and Web Developers. This was the first step 
in identifying the major categories of IT occupations. However, this list from $\mathrm{OOH}$ appeared to be missing several important occupations available to students. These included the areas of Software Quality Assurance, Technical Writer, and Computer Hardware Engineers. Therefore, these were added to the list as possible IT occupations. It also became apparent that IS programs could not possibly prepare students for all of these occupations. This created the need to further categorize each occupation in two different ways. The first was by level (entry, mid, advanced) and the second by career path (software development, technical support, and management/consulting). Although this research project focuses on IS degrees, it is important to note that computer programmers and software developers are primarily the focus of Computer Science programs.

IT Career Levels

Many of the Computer and IT Occupations listed in the $\mathrm{OOH}$ and on job sites, like Dice.com, require certain skills and experience. Fortunately, $\mathrm{OOH}$ provides this information for each occupation. For the purpose of this research project, experience was organized into the three levels of entry-level, mid-level, and advanced-level occupations. Entry-level occupations require no work experience in a related occupation. Mid-level occupations require less than five years of experience in a related occupation. Advanced-level occupations require more than five years of experience in a related occupation or advanced degrees, like a Ph.D. Most IS programs have limited credits available to allocate, which impact the number and type of courses offered. Therefore, it would make the most sense to focus on courses that would prepare students for entry-level careers. Again, this would allow faculty the ability to design and focus their curriculum to have the most impact on undergraduate students being prepared for the job market upon graduation.

\section{IT Career Tracks}

In addition to the IT Career Levels, it also became apparent that Computer and IT Occupations could be organized by tracks. The main types of occupations fell into the three categories of Software Development, Technical Support, and Management/Consulting. Organizing the occupations this way could also help students understand the main career opportunities but also aid in selection of electives offered by their respective IS program. Some IS majors enjoy programming and could focus on this area. Others prefer installing and supporting hardware/software and could focus on the technical support side. The career tracks also show students the opportunities for advancement within each career track but also possibilities to move into management or consulting. This research project focuses primarily on the entry-level occupations. Table 3 summarizes the Computer and IT Occupations by IT Career Tracks and Levels.

Table 3. Computer and IT Occupations by Career Tracks and Levels

\begin{tabular}{|l|l|l|l|}
\hline IT Career Track & \multicolumn{3}{|c|}{ Job Titles (www.bls.org) } \\
\hline & \multicolumn{1}{|c|}{$\begin{array}{c}\text { Entry-Level } \\
\text { No experience required }\end{array}$} & $\begin{array}{c}\text { Mid-Level } \\
\text { 5 yrs or less experience req }\end{array}$ & $\begin{array}{c}\text { Advanced-Level } \\
\text { 5+ yrs experience or Ph.D. }\end{array}$ \\
\hline $\begin{array}{l}\text { Software } \\
\text { Development }\end{array}$ & $\begin{array}{l}\text { Computer Programmer, } \\
\text { Computer System Analyst, } \\
\text { Software Developer, Quality } \\
\text { Assurance/Tester, Web } \\
\text { Developer }\end{array}$ & $\begin{array}{l}\text { Database Administrator, } \\
\text { Technical Writer }\end{array}$ & \\
\hline $\begin{array}{l}\text { Technical } \\
\text { Support }\end{array}$ & $\begin{array}{l}\text { Computer Hardware } \\
\text { Engineer, Computer Support } \\
\text { Specialist, Computer } \\
\text { Systems Administrator, } \\
\text { Network Administrator }\end{array}$ & $\begin{array}{l}\text { Information Security } \\
\text { Analyst }\end{array}$ & $\begin{array}{l}\text { Computer and Information } \\
\text { Research Scientist, } \\
\text { Computer Network } \\
\text { Architect }\end{array}$ \\
\hline $\begin{array}{l}\text { Management \& } \\
\text { Consulting }\end{array}$ & & & $\begin{array}{l}\text { CIO, CTO, Chief Security } \\
\text { Officer (CSO), Computer } \\
\text { and IS Manager, Consultant, } \\
\text { Project Manager }\end{array}$ \\
\hline
\end{tabular}

Therefore, the research identified 20 IS occupations, which included nine entry-level, three mid-level and eight advanced-level occupations. Therefore, the hypothesis of seven or higher was supported for the entry-level and advanced-level but not for the mid-level occupations. The mid-level occupations may not be as accurate since many of the entry-level positions allow for promotion to mid-level, which is difficult to show on a table. 


\section{Issues in Information Systems \\ Volume 18, Issue 3, pp. 78-88, 2017}

\section{Results for Step Two (RQ2) - IS Programs Preparing Students for IS Occupations}

The second step was relating IS courses to Computer and IT Occupations by identifying the amount of coverage in each course for each occupation and creating an IT Career Index. This was best accomplished through the use of a chart/figure and an index. The chart lists the entry-level and mid-level IT Careers identified in Step One along the side and the required and electives course in an IS program along the top. Separating the courses in this way allows faculty to analyze their programs and electives separately, since not all students take all the electives. For the index, each IS course was scored with either an "s" for some coverage or an "M" for Major coverage of the technical skills for the respective occupation. This approach was similar to IS 2010 but adds the IT Career Levels to the occupations (Topi, et al., 2010). The assignment of an "s" versus an "M" was a judgment call by the IS faculty member creating the index or possibly could be done as a joint effort by a group of faculty members. The index was then calculated by assigning a numerical value of two for each "s" and five for each "M". These values (numbers) could easily be adjusted as needed by other institutions. This allows a total score to be calculated for each occupation, one for the required IS courses and a second one for the IS electives. The end result provides an IT Career Index for each occupation (required and electives). Once a chart is completed for an IS program, the indices can highlight obvious strength areas and possible areas for changes and/or improvements. Of course, additional work must be done to reduce as much subjectivity as possible in the scoring. In addition, detailed job specifications could be used as a comparison to the learning objectives of each course. Since there are no current skills sets standards for Computer and IT Occupations, this will be challenging. However, this is a start to connecting IS programs and entry-level occupations in the IT industry. The next section provides examples of completed IT Career Indexes for a CIS Program at a mid-sized, public institution in southern New England, one for an IS Program at a mid-sized public institution in Pennsylvania, and one for a MIS Program at a large public institution in Mississippi. Of the most common IS-related program names, these three were available to the researchers.

In order to address the research questions, it was necessary to identify what score would dictate "a majority of the skillsets". For this it was decided that at least two courses with an "M" score and two courses with an "s" score would dictate a majority. Since each "M" scores a five and each "s" scores a two, then the index would need to equal at least $14((\mathrm{M} \times 2)+(\mathrm{s} \times 2)>=14)$. Therefore, IT Career Indices of 14 or greater would support the hypothesis.

\section{Results - IT Career Index for the CIS Program}

For the CIS program, all five of the entry-level occupations in the Software Development track had an IT Career Index of 14 or greater. These included Computer Programmer (17), Computer Systems Analyst (20), Software Developer (20), QA/Tester (17) and Web Developer (14). For the Software Development electives, three of the occupations had an IT Career Index of 14 or greater. These included Computer Programmer (17), Software Developer (15), and QA/Tester (15). Computer System Analyst scored the lowest with 0 and Web Developer scored a 7.

All four of the entry-level occupations in the Technical Support track scored a 12. These included Computer Hardware Engineer (12), Computer Support Specialist (12), Computer Systems Administrator (12), and Network Administrator (12). For the Technical Support electives, only one of the current electives in the CIS program provided coverage of topics for these occupations. This resulted again in the exact same score (5) for all four occupations.

Therefore, the index supports the hypothesis that this particular CIS Program provides a majority (IT Career Index 14 or higher) of the skillsets needed for entry level IT positions in the Software Development track. The index did not support the hypothesis for entry level positions in the Technical Support track. Table 4 provides a summary of the scores as well as a comparison to the other IS programs and to IS 2010. Mid-level Occupations are provided for information only and are not discussed as part of this research project.

\section{Results - IT Career Index for the IS Program}

For the IS program, the only entry-level occupation in the Software Development track that had an IT Career Index of 14 or higher was Computer Systems Analyst with a score of 16. Three had a score of 13, Computer Programmer, Software Developer, and QA/Tester. Web Developer had the lowest score of 10. For the Software Development electives, all had an IT Career Index of 14 or greater. 
All four of the entry-level occupations in the Technical Support track scored a 10. These include Computer Hardware Engineer (10), Computer Support Specialist (10), Computer Systems Administrator (10), and Network Administrator (10). For the Technical Support electives, two of the current electives in the IS program provided coverage of topics for these occupations.

Therefore, the index does not fully support the hypothesis that this particular IS Program provides a majority (IT Career Index 14 or higher) of the skillsets needed for entry level position in the Software Development Track. The index also did not support the hypothesis for entry-level positions in the Technical Support track. These results are aligned with the goal of the IS Program to primarily prepare graduates for Business Analyst/Computer Systems Analyst types of positions. Table 4 provides a summary of the scores as well as a comparison to the other IS programs and to IS 2010. Mid-level Occupations are provided for information only and are not discussed as part of this research project.

\section{Results - IT Career Index for the MIS Program}

For the MIS program, only courses with the MIS prefix were considered for this analysis, even though the department allows students to take elective courses from other departments such as Computer Science. The relative scoring for the courses came primarily from the MIS course catalog for the 2016/17 academic year.

There are nine total courses with the MIS prefix, which are considered required for all active MIS undergraduate majors. All five of the entry-level occupations in the Software Development track had an IT career index of 14 or greater. This included Computer Programmer (30), Computer Systems Analyst (27), Software Developer (36), QA/Tester (24), and Web Developer (24). The Software Developer occupation scored the highest while QA/Tester and Web Developer both scored the lowest. For the Software Development track occupations for the elective courses, no occupation scored a 14 or higher, indicating the prevalence of required courses over electives with an MIS prefix. Computer Programmer and Software Developer both scored a 5 while Computer Systems Analyst, QA/Tester, and Web Developer each scored a 2.

None of the four entry-level occupations in the Technical Support track scored a 14 or higher. This included Computer Hardware Engineer (10), Computer Support Specialist (13), Computer Systems Administrator (13), and Network Administrator (10). Similarly, for the Technical Support track occupations for the elective courses, no occupation scored a 14 of greater. Computer Support Specialist and Computer Systems Administrator both scored a 5 while Computer Hardware Engineer and Network Administrator both scored a 2.

The index supports the hypothesis that this MIS program provides a majority (IT Career Index 14 or higher) of the skillsets needed for entry-level positions in the Software Development track. The index did support the hypothesis for two entry-level positions in the Technical Support track, but only after MIS electives are included in the analysis. Table 4 provides a summary of the scores as well as a comparison to the other IS programs and to IS 2010. Mid-level Occupations are provided for information only and are not discussed as part of this research project.

\section{Results - IT Career Index for IS 2010}

The IS 2010 index used the scoring from the IS 2010 report except in the case of the Technical Support occupations, which were not included in the IS 2010 report. In addition, the job titles used in the IS 2010 report differed from the job titles used by BLS and adjustments or omissions were made as needed. One major difference between the indexes of the CIS, IS and MIS programs and the IS 2010 index was the scoring of the required courses. In the case of IS 2010, every course received either "Some Coverage" or "Significant Coverage". This actually caused the other indexes to be re-scored using a similar approach for the required courses.

For IS 2010, all five of the entry-level occupations in the Software Development track had an IT Career Index of 14 or greater. This included Computer Programmer (26), Computer Systems Analyst (26), Software Developer (26), QA/Tester (26) and Web Developer (23). In addition, the scores were very similar across all five occupations. For the Software Development electives, all five again had an IT Career Index of 14 or greater and similar scores except 
for Computer Systems Analyst (24), which scored the highest. Computer Programmer (14), Software Developer (14), QA/Tester (14) and Web Developer (18) were within a few points of each other.

All four of the entry-level occupations in the Technical Support track had an IT Career Index of less than 14 except Network Administrator. This included Computer Hardware Engineer (5), Computer Support Specialist (9), and Computer Systems Administrator (9). Only the Network Administrator (20) of the entry-level occupations in the Technical Support track scored higher than 14 with a score of 20. For the Technical Support electives, only one of the entry-level occupations had scoring and this was the Network Administrator (15).

Therefore, the index supports the hypothesis that the IS 2010 recommendation provides a majority (IT Career Index 14 or higher) of the skillsets needed for entry-level IT positions in the Software Development track. The index did not support the hypothesis for entry-level positions in the Technical Support track except for Network Administrator. Table 4 provides a summary of the scores as well as a comparison to the IS programs. Mid-level Occupations are provided for information only and are not discussed as part of this research project.

Table 4. Summary and Comparison of IT Career Indexes

\begin{tabular}{|c|c|c|c|c|c|c|c|c|}
\hline & \multicolumn{2}{|c|}{ CIS } & \multicolumn{2}{|c|}{ IS } & \multicolumn{2}{|c|}{ MIS } & \multicolumn{2}{|c|}{ IS 2010} \\
\hline & Req. & Elec. & Req. & Elec. & Req. & Elec. & Req. & Elec. \\
\hline \multicolumn{9}{|l|}{$\begin{array}{l}\text { Software Development } \\
\text { Entry-Level }\end{array}$} \\
\hline Computer Programmer & 17 & 17 & 13 & 21 & 30 & 5 & 26 & 14 \\
\hline Computer Systems Analyst & 20 & 0 & 16 & 15 & 27 & 2 & 26 & 24 \\
\hline Software Developer & 20 & 15 & 13 & 21 & 36 & 5 & 26 & 14 \\
\hline QA/Tester & 17 & 15 & 13 & 18 & 24 & 2 & 26 & 14 \\
\hline Web Developer & 14 & 7 & 10 & 21 & 24 & 2 & 23 & 18 \\
\hline \multicolumn{9}{|l|}{ Mid-Level } \\
\hline Data/Database Administrator & 17 & 0 & 13 & 2 & 21 & 2 & 23 & 17 \\
\hline Technical Writer & 17 & 0 & 10 & 2 & 18 & 2 & 17 & 0 \\
\hline \multicolumn{9}{|l|}{$\begin{array}{l}\text { Technical Support } \\
\text { Entry-Level }\end{array}$} \\
\hline Computer Hardware Engineer & 12 & 5 & 10 & 12 & 10 & 2 & 5 & 0 \\
\hline Computer Support Specialist & 12 & 5 & 10 & 12 & 13 & 5 & 9 & 0 \\
\hline Computer Sys Administrator & 12 & 5 & 10 & 12 & 13 & 5 & 9 & 0 \\
\hline Network Administrator & 12 & 5 & 10 & 12 & 10 & 2 & 20 & 15 \\
\hline \multicolumn{9}{|l|}{ Mid-Level } \\
\hline Information Security Analyst & 12 & 5 & 10 & 6 & 18 & 4 & 17 & 10 \\
\hline
\end{tabular}

\section{SUMMARY}

\section{Scoring - Required v. Elective Courses}

The scoring of the IT Career Index is very subjective to the person completing the scoring. However, the scoring for this research project was done with collaboration between the three researchers, but ultimately resided with the researcher associated with his/her institution. There are no guidelines for assigning a course either an "s" or an "M" other than the knowledge, experience and background of the scorer. It can only be assumed that faculty could possibly disagree on whether a certain course provides some or significant coverage of topics needed for entry-level IT occupations. In the case of IS 2010, one could argue that Enterprise Architecture (IS 2010. 3) and IS Strategy, Management, and Acquisition (IS 2010.6) do not provide skills needed for an entry-level computer programmer. The benefit of the doubt must be used here. These courses appear to focus on mid-level and advanced-level IT occupations. The other issue with the scoring is with the electives, which are different from required courses in that not all electives are taken by all students. In many IS Programs, the electives are limited to a set number providing flexibility and options (and possibly tracks) to students. In addition, the electives to do take into account "special topics" courses. 


\section{Issues in Information Systems}

Volume 18, Issue 3, pp. 78-88, 2017

\section{Software Development v. Technical Support}

Overall, the Software Development track scored higher that the Technical Support track for all four (CIS, IS, MIS, and IS 2010) programs. This may indicate that IS programs, regardless of their name, focus on this area in their curriculum. Future research should evaluate Information Technology programs versus IS programs. However, students wanting to pursue a career in Technical Support may not have the option of an Information Technology program available in their area. Therefore, the question remains whether IS programs should try to provide both career tracks to students. Many institutions may not have the resources to do so, resulting in choosing one over the other or just providing minimal coverage.

\section{Recommendations}

For the benefit of students, IS should consider standardizing program names that focus on Information Systems and educating high school students about this field of study. Computer Science has one name and is universally recognized by most people, including students and working professionals. In addition, Faculty in IS programs need to determine their focus and the type of jobs for their students in their region and adjust courses according to the local IT job market. IS curriculum that are focused in this way can provide students with more of the possible skills sets for obtaining entry-level occupations upon graduation. This will not only benefit the student in many ways but also has the potential for increasing enrollments in IS programs.

\section{REFERENCES}

Aasheim, C., Shropshire, J., Li, L., \& Kadlec, C. (2012). Knowledge and skill requirements for entry-level IT workers: A longitudinal study. Journal of Information Systems Education, 23(2), 193.

Akbulut, A. Y. (2015). The Impact of the Introductory IS Course on Students' Perceptions of IS Professionals. Journal of Information Systems Education, 26(4), 295.

Focuses on recruitment into the major based on image of IS

Bain, L.Z., Choi, K., \& Hayden, M. (2016). A First Attempt at Improving Student Engagement by Understanding Student Perceptions and Barriers to IT Career Development. Information Systems Education Conference (ISECON) Proceedings. Baltimore, MD.

Brooks, N., Korzaan, M., \& Ceccucci, W. (2014). A preliminary comparison of student and professional motivations for choosing information systems. Information Systems Education Journal, 12(4), 49.

Burns, T. J., Gao, Y., Sherman, C., Vengerov, A., \& Klein, S. (2014). Investigating a 21st century paradox: As the demand for technology jobs increases why are fewer students majoring in information systems? Information Systems Education Journal, 12(4), 4.

Chipidza, W., Green, G., \& Riemenschneider, C. (2016). Salient Beliefs in Majoring in Management Information Systems: An Elicitation Study. Information Systems Education Journal, 14(4), 69.

CS4RI (2016). Computer Science for All Rhode Island. Retrieved April 9, 2016 from http://www.cs4ri.org/

Feinstein, D., Longenecker, B., \& Shresthat, D. (2014). A Study of Information Systems Programs Accredited by ABET In Relation to IS 2010. Information Systems Education Journal, 12(3), 76.

Hayen, R. L. (2012). IS Major Analysis: A Framework for Evaluating Emerging Trends. Issues in Information Systems, 13(2), 238-247.

Hwang, D., \& Curl, S. (2014). The Market for Career Tracks in Undergraduate IS Curricula in the US. Information Systems Education Journal, 12(3), 4. 
Janicki, T., Cummings, J., \& Kline, D. M. (2014). Information Technology Job Skill Needs and Implications for Information Technology Course Content. Information Systems Education Journal, 12(6), 59.

Lang, G., Jones, K., \& Leonard, L. N. (2015). In the know: desired skills for entry-level systems analyst positions. Issues in Information Systems, 16(1), 142-148.

Legier, J., Woodward, B., \& Martin, N. L. (2013). Reassessing the skills required of graduates of an information systems program: An updated analysis. Information Systems Education Journal, 11(3), 79.

Lenox, T., Jesse, G., \& Woratschek, C. R. (2012). Factors influencing students decisions to major in a computerrelated discipline. Information Systems Education Journal, 10(6), 63.

Li, L., Zhang, C., \& Zheng, G. (2014). Promoting Information Systems Major to Undergraduate Students-A Comprehensive Investigation. Journal of Information Systems Education, 25(3), 211.

Lytle, R. (2012). Computer Science Continues Growth on College Campuses. U.S. News \& World Report. Retrieved May 2, 2017 from https://www.usnews.com/education/bestcolleges/articles/2012/07/12/computer-science-continues-growth-on-college-campuses.

Munro, D., \& Ambrose, P. (2012). An Investigation of General Perceptions of the IT Workforce. Issues in. Information Systems, 13(2), 346-352.

Snyder, J., \& Slauson, G. (2014). Majoring in information systems: reasons why students select (or not) information systems as a major. Information Systems Education Journal, 12(3), 59.

Surendran, K., Amer, S., \& Schwieger, D. (2012). CIS Program Redesign Driven By IS2010 Model: A Case Study. Information Systems Education Journal, 10(5), 37.

Thatcher, J. (2017). A Message from the President. AIS InSider. Retrieved May 2, 2017 from http://aisnet.org/news/news.asp?id=328616\&hhSearchTerms=\%22enrollments\%22.

Topi, H., Valacich, J.S., Wright, R.T., Kaiser, K.M., Nunamaker, J.F., Sipior, J.C., \& de Vreede, G.L. (2010). Curriculum Guidelines for Undergraduate Degree Programs in Information Systems. Retrieved June 24, 2016 from http://www.acm.org/education/curricula-recommendations.

Veltri, N. F., Webb, H. W., Matveev, A. G., \& Zapatero, E. G. (2011). Curriculum mapping as a tool for continuous improvement of IS curriculum. Journal of Information Systems Education, 22(1), 31.

Westfall, R. D. (2012). An Employment-Oriented Definition of the Information Systems Field: An Educator's View. Journal of Information Systems Education, 23(1), 63. 